\title{
MARINGÁ - A PAISAGEM URBANA E O SISTEMA DE ESPAÇOS LIVRES
}

\author{
MARINGÁ - URBAN LANDSCAPE AND THE OPEN SPACES SYSTEM
}

Karin Schwabe Meneguetti

Arquiteta UFPR e doutora pela FAUUSP.

\section{Renato Leão Rego}

Arquiteto UEL e doutor pela Universidad Politécnica de Madrid.

\section{Gislaine Elizete Beloto}

Arquiteta UEL e mestre pela UEM.

Departamento de Arquitetura e Urbanismo

Universidade Estadual de Maringá - UEM

e-mail: ksmeneguetti@uem.br

\section{RESUMO}

Desde sua origem, Maringá se diferenciou das demais cidades brasileiras. Trata-se de uma cidade planejada, segundo um modelo urbanístico muito atento a questões ambientais, geográficas, hidrográficas, ecológicas e sanitárias, sem desconsiderar ou menosprezar os fatores estéticos. A cidade se encontra, hoje, com qualidade urbana razoável, comprovando que a forma urbana inicial configurou uma resposta projetual bastante adequada aos processos naturais, aproximando-se dos requisitos da sustentabilidade urbana.

Maringá tem conseguido manter a forma do plano original com poucas modificações nas áreas livres originalmente propostas, embora as áreas de expansão não tenham mantido as mesmas características e qualidades espaciais. Com base nesse quadro, este artigo pretende refletir sobre tópicos da conformação da paisagem urbana de Maringá e sua implicância no atual sistema de espaços livres da cidade.

Palavras-chave: Maringá, espaços livres, paisagem urbana, morfologia urbana.

\begin{abstract}
Maringá has always been a special city. It was a totally planned new town whose planning was based upon an urban model that has been aware of environmental, geographical, hydrographical, and ecological issues, without disregarding aesthetics matters. According to current parameters for urban sustainability, the city still holds reasonable levels of urban qualities, which states that the original urban form was a proper response to natural processes.

Originally-planned open spaces have basically preserved their original characteristics over the years. However, recent expansion areas have not reproduced those remarkable spatial characteristics and qualities of the original city layout. Based on this situation, this paper aims to reflect upon Maringa's landscape and its implications in the present system of urban open spaces.
\end{abstract}

Key words: Maringá, open spaces, urban landscape, urban morphology. 


\section{INTRODUÇÃO: SOBRE A CENA NATURAL}

Alguns dados sobre a base geográfica de Maringá vão ajudar a identificar sua paisagem natural. É importante conhecê-la para se compreender a relação entre a forma urbana e o sítio e as qualidades espaciais e ambientais daí decorrentes.

município está situado no noroeste do estado do Paraná, em área de abrangência dos basaltos da formação Serra Geral. O perfil geomorfológico do município é predominantemente suave, entre 500 e 600 metros de altitude, constituído por grandes extensões com baixas declividades. Nessa região "de terra roxa", os topos dos derrames possuem menor resistência ao intemperismo que, sob a ação da erosão, formam relevos do tipo cuesta ou meseta.

Essas deformações são observadas em alinhamentos, formando vales aprofundados, a exemplo dos ribeirões Bandeirantes do Sul e Paiçandu, que limitam a expansão urbana da cidade de Maringá no sentido oeste. $\bigcirc$ alinhamento que secciona o município na direção leste-oeste, formando uma zona de crista ou alto topográfico, configura um grande divisor de águas, orientando a drenagem pluvial no sentido transversal em direção à bacia do rio Paranapanema, ao norte, e à bacia do rio Ivaí, ao sul (MARINGÁ, 1996). Assim, na área urbana da cidade de Maringá, os córregos Ibipitanga, Nazareth, Mandacaru, Miosótis, Osório, Guaiapó e os ribeirões Maringá e Morangueiro deságuam no rio Pirapó, contribuinte do rio Paranapanema, enquanto os córregos Burigui, Borba Gato, Cleópatra e Moscados e, ainda, os ribeirões Bandeirantes do Sul, Paiçandu, Floriano e Pingüim constituem afluentes do rio Ivaí.

Como a cidade está localizada sobre esse divisor de águas, os cursos d'água nascidas na zona urbana são de volume e dimensões reduzidos. Por um lado, isso limita a oferta de água para abastecimento da população. Por outro, impõe a necessidade de adotar-se critérios rigorosos quanto às descargas de águas pluviais e de águas servidas nesses corpos receptores, a fim de evitar a detonação de processos erosivos em suas cabeceiras e margens e a polvição de seus caudais.

Muitos cursos d'água que atravessam a área urbana possuem leitos encaixados em vales profundos, formando ravinas provocadas por processos erosivos, cuja ocorrência foi desencadeada pelo uso inadequado do solo, uma vez que o desmatamento desenfreado eliminou boa parte das matas ciliares necessárias à prevenção e ao controle da erosão.

A região de Maringá era, originalmente, coberta pela floresta estacional semidecidual submontana, abundante em espécies como o cedro, a peroba, o ipê, o pau-d'alho e a canela, que foram dizimadas na primeira metade do século com a colonização, a expansão da cultura cafeeira e a descoberta de seu potencial econômico para a construção civil e a indústria moveleira. A intervenção humana contribuiu com a derrubada e as queimadas sistemáticas dos campos, tanto para eliminar a principal vegetação nativa quanto para o surgimento de matas secundárias, capoeiras e vegetação rasteira.

Atualmente, são raros os locais do município onde subsistem remanescentes da vegetação original da região. Assim, a cobertura florestal primitiva mais significativa 
está restrita à área urbana, por meio das reservas de matas nativas encontradas no Horto Florestal, no Parque do Ingá e no Bosque II, que somam 2.346.384,84 m², representando $1,8 \%$ da área total da cidade. Embora constituída por espécies, em sua maioria, estranhas à região, é expressiva a arborização pública implantada nos canteiros centrais e passeios laterais de avenidas, ruas e praças que, somada à área das reservas de matas nativas acima referidas, representam, aproximadamente, 5,0\% da área urbana, não incluídos aí os remanescentes de matas ciliares encontrados nos fundos de vales os quais atravessam a cidade (MARINGÁ, 2000).

\section{A PAISAGEM PRODUZIDA}

A intenção projetual de dotar a cidade de Maringá com estruturas compatíveis à morfologia do terreno fez de seu projeto inicial a gênese de uma forma coerente com os processos ambientais que começariam a ser discutidos, com maior força, na segunda metade do século XX (MCHARG, 1992).

Maringá foi projetada pelo engenheiro Jorge de Macedo Vieira, a pedido da Companhia Melhoramentos Norte do Paraná (CMNP), responsável pela colonização do norte do Paraná. Como se sabe, não só o desenho da cidade de Maringá como outros projetos de Macedo Vieira demonstram forte influência dos princípios formais da cidade-jardim inglesa (STEINKE, 2007; REGO e MENEGUETTI, 2005). Seguindo a prática projetual da Companhia, o engenheiro urbanista desenvolveu o projeto urbano a partir um rigoroso levantamento planialtimétrico da área (ainda protegida por sua densa cobertura florestal), o que garantiu a qualidade da implantação e a individualidade da forma urbana. Era a prática do escritório técnico da companhia adaptar o padrão de um traçado urbano (normalmente regular e geométrico) às circunstâncias geográficas do sítio escolhido para se implantar uma nova cidade.

No caso de Maringá, a escolha do sítio e o traçado da cidade foram condicionados pelo traçado da via férrea em construção, no sentido leste-oeste, e por dois pequenos vales ao sul. $\bigcirc$ trajeto da linha férrea, coincidindo com os principais divisores de águas, determinou a implantação da cidade na área mais elevada e seca, atingindo poucas nascentes de rios; essa localização também livrou o projeto inicial de grandes declividades ou áreas impróprias à ocupação. Os dois vales ao sul da ferrovia foram delimitados como parques urbanos, preservando as duas nascentes aí existentes, espécies de pulmões urbanos os quais, de acordo com Vieira (1972), serviriam "para que a população do futuro pudesse conhecer a vegetação da época da colonização e também para que a cidade jamais viesse a sofrer com problemas de polvição" (Figura 1).

O centro cívico, o elemento principal do plano, foi posicionado entre esses parques e a linha férrea, em área praticamente plana. A praça principal se conecta com o lugar da antiga estação ferroviária por um bulevar, um cenário marcante da paisagem urbana, particularmente realçado pelo edifício da Catedral - um cone de concreto, 100 metros de altura, posicionado ao final desse bulevar, na praça, no formato de crescent. 


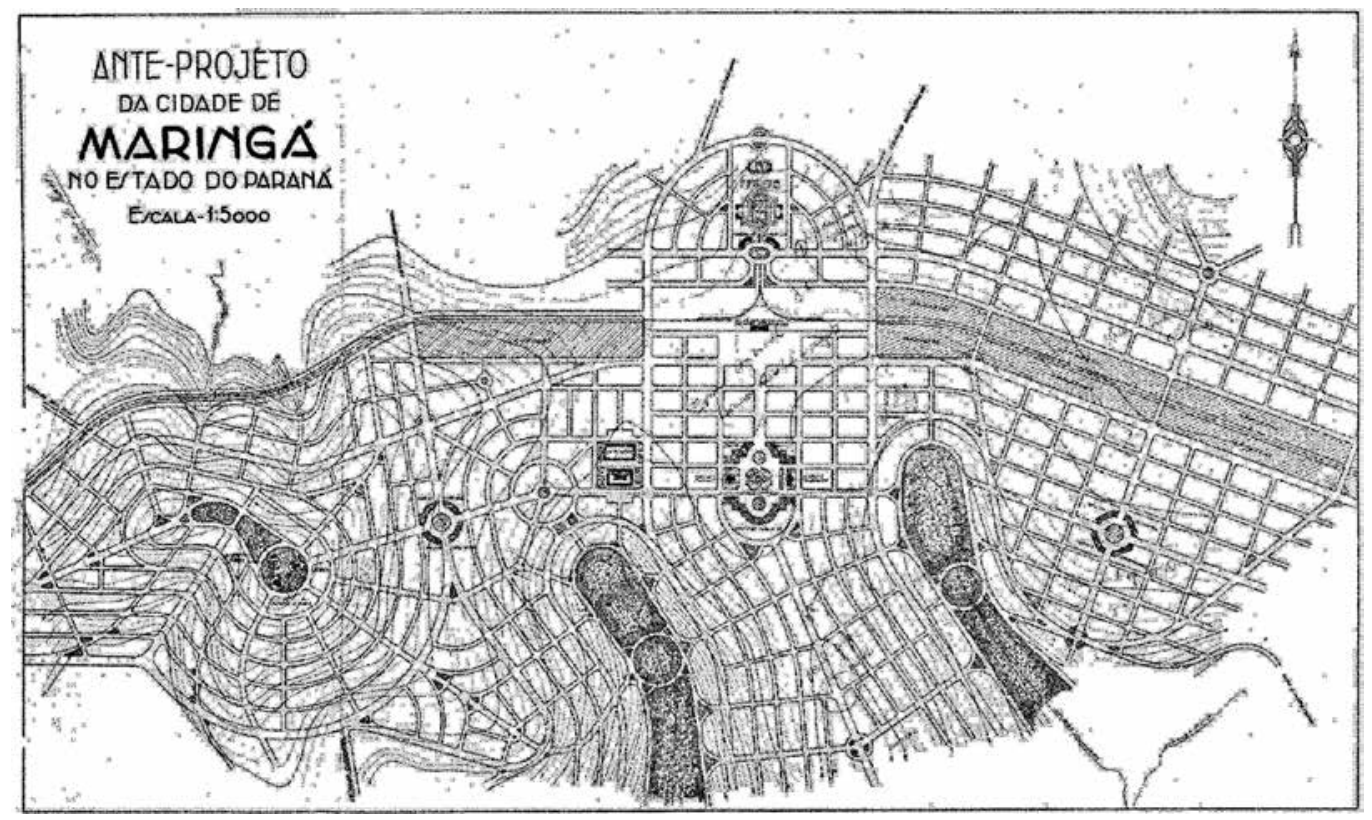

Figura 1: Anteprojeto de Maringá - Jorge de Macedo Vieira Fonte: Prefeitura de Maringá

O relevo mais plano desse quadrilátero central permitiu o traçado das vias em tabuleiro de xadrez e reforçou o caráter mais simbólico e monumental dado ao espaco urbano central (REGO et al, 2004).

Em contraste com a força apelativa da malha ortogonal central, pode-se notar o caráter diferenciado de cada um dos bairros do plano original, distintos pelos traçados mais orgânicos das vias, delimitados por elementos bem definidos - avenida, bosque, via férrea, organizados em torno de pontos de interesse, geralmente definidos a partir de convergências de vias importantes ou de sua posição central dentro do bairro. Em cada bairro pode-se perceber a intenção projetual de constituir um centro secundário, com comércio e serviços em torno de uma praça. Isso representava um ponto focal e um elemento fundamental para a legibilidade urbana, sem contar que assim também se garantia a acessibilidade dos moradores ao comércio e serviços vicinais em tempos de negação ao veículo particular.

As vias que deixam o centro e conduzem às zonas secundárias nos lados sul e oeste da cidade adquirem, predominantemente, um traçado consoante com as curvas de nível, logrando variedade com o movimento orgânico das pendentes e com a arborização urbana.

Dentro do traçado mais orgânico, chamam a atenção as rotatórias, para aonde convergem as vias principais e onde são articuladas as vias retas e curvas. Originalmente previstos apenas como elementos de articulação do sistema viário, essas rotatórias se tornaram praças, ainda que sua ocupação tenha acarretado certos conflitos entre o automóvel e o pedestre. De toda sorte, esses elementos se caracterizam como pontos focais na paisagem. 
É notável a hierarquia entre as vias principais e secundárias, diferenciadas pela largura $(20,30,35$ e 40 metros), pela eventual presença do canteiro central e variedade de espécies empregada na arborização urbana. Na área do projeto original, ainda hoje cada rua ou avenida pode ser identificada por sua espécie arbórea.

A rigor, as vias de traçado ortogonal são proporcionalmente mais curtas que as vias curvas e irregulares, menos monótonas e mais variadas. As retas desenhadas pelas primeiras têm definidos seus pontos iniciais e finais, de modo a garantir um limite e um atrativo à paisagem da rua. Durante a implantação da cidade e em suas primeiras décadas, a largura das vias era desproporcional à ocupação, embora isso incrementasse a idéia de uma cidade planejada e moderna. Com o tempo, a vegetação criou uma cobertura para a via pública e melhorou as condições do clima urbano. Com calçadas largas e densa e rica vegetação urbana, a rua também é lugar de passeio e, dada essa carcaterística, pode, até certo ponto, ser considerada dentro do sistema de espaços livres.

As quadras residenciais e comerciais de aproximadamente um hectare foram desenhadas respeitando o formato retangular ( $144 \mathrm{~m} \times 80 \mathrm{~m}$ em geral). Entretanto, a adoção do traçado orgânico imprimiu algumas modificações a essa forma ideal. De qualquer modo, elas foram subdivididas em lotes de $500 \mathrm{~m}^{2} \mathrm{em}$ média, dando lugar a jardins privados a ampliarem para dentro do lote a massa verde que cobre as largas calçadas públicas. As áreas de permeabilidade estariam, assim, garantidas, colaborando para a diminuição do escoamento superficial das águas pluviais.

A partir de uma anotação no anteprojeto de Macedo Vieira, a cidade ficou subdividida em três zonas residenciais (principal, popular e operária), zona industrial, zona comercial, dependências e armazéns da estrada de ferro e os núcleos comerciais, sempre com um limite preciso - seja bosque ou avenida. Contudo, o desenho urbano acabou por conferir caráter próprio às diferentes áreas da cidade, iá que o parcelamento dos lotes foi uniforme.

As praças eram em número de 35 e, somadas aos dois parques, perfaziam 195.591,18 $\mathrm{m}^{2}$ de área livre, em um total de 1,3\% da área bruta do plano original. Mas a maior parte delas tem função estrutural no traçado viário, constituindo-se de rótulas ou largos criados pela confluência de vias. Algumas reforçam o caráter simbólico, como já descrito, e poucas têm função específica de local de encontro.

A proteção das nascentes dos principais córregos, sujeitas à erosão, por meio da localização dos parques com área remanescente da floresta nativa, foi encampada pela empresa loteadora, que, ciente das condições adversas do clima local, uma vez livre de sua cobertura vegetal, adotou a farta arborização das vias como diferencial de conforto urbano e imagem da cidade.

Assim, a Companhia recorreu aos serviços técnicos de um engenheiro florestal e, para a viabilização do plano de arborização, criou o Horto Florestal em uma área de 37 hectares de mata nativa. As espécies arbóreas vieram, basicamente, do Serviço Florestal de São Paulo, da ESALQ, mas também foram utilizadas espécies nativas, como o ipê roxo e a sibipiruna, pela colheita de sementes diretamente da mata. 


\section{EVOLUÇÃO URBANA}

O modo como se deu a evolução urbana dessa cidade planejada pode colaborar para o entendimento de uma perda da qualidade espacial e das áreas livres, em particular na faixa da expansão urbana, além do plano original.

A ocupação urbana na área da cidade de Maringá começou em 1942, a partir de um pequeno núcleo inserido na mata fechada. Esse núcleo foi cuidadosamente administrado para não se estabelecer como definitivo, enquanto se aguardava a localização exata da futura linha férrea, a derrubada da mata para a marcação do desenho urbano e a implantação da cidade efetivamente. A pedra fundamental de Maringá foi lançada em 10 de maio de 1947.

O dinamismo do desenvolvimento regional, bem como da incipiente cidade, e as dificuldades impostas pela CMNP na compra dos lotes, a fim de garantir a rápida urbanização, estimularam outras empreendedoras a lotearem glebas rurais próximas à cidade, vendidas pela CMNP para fins agrícolas (MARINGÁ, 2000).

Esses loteamentos, realizados em paralelo à cidade oficial e comercializados para uma população menos favorecida, já possuíam um padrão urbanístico diferenciado, com ruas, quadras e lotes de menores dimensões, sem continuidade viária com o projeto de Jorge Macedo. Muitos desses loteamentos se encontravam sobre faixas de proteção dos córregos e tinham áreas livres de uso público em número e tamanho insuficientes. Desse modo, a mancha urbana foi perdendo concentração, identidade, legibilidade e qualidade espacial.

Com a elevação de Maringá à categoria de município em 1951, a configuração de espaços urbanos passou a ser normatizada pelas leis urbanísticas, as quais substituíram o controle que a Companhia tinha sobre o território da cidade. Com efeito, em 1959 foi aprovado o primeiro documento de controle urbanístico, o Código de Posturas e Obras, Lei n. 34/59. De características bastante rígidas e autoritárias, esse documento determinava o zoneamento e estabelecia as regras para o parcelamento do solo, bem como normas rigorosas do ponto de vista ambiental, mas apenas reconhecia como cidade a área implantada pela companhia.

Nos anos 60, Maringá apresentou um extraordinário ritmo de crescimento, sendo criados dez novos loteamentos, significando um aumento de quase $50 \%$ no total de lotes na cidade em dez anos. A população urbana mais que dobrou e a ampliação do perímetro urbano gerou um desequilíbrio no crescimento ordenado e eficaz do plano inicial, isolando os loteamentos periféricos, que levaram muitos anos para se equipararem às demais áreas da cidade.

Em 1967 o governo do estado do Paraná financiou o primeiro plano diretor de Maringá - a Lei Municipal n. 621 de 1968. De forte apelo racional e teórico-metodológico modernista, priorizava o sistema viário em detrimento da paisagem urbana. Apesar disso, esse plano representou um trabalho de grande relevância por ser o responsável pela gênese dos corredores ecológicos, ao adotar faixas de proteção ao longo dos córregos, mesmo com dimensões e funções aquém da estrutura que originava (Figura 2). Suas 
propostas viárias não foram levadas a cabo, o que poderia ter interferido negativamente nas qualidades ambientais do projeto original, mas a concepção dos corredores foi, gradativamente, sendo implementada.

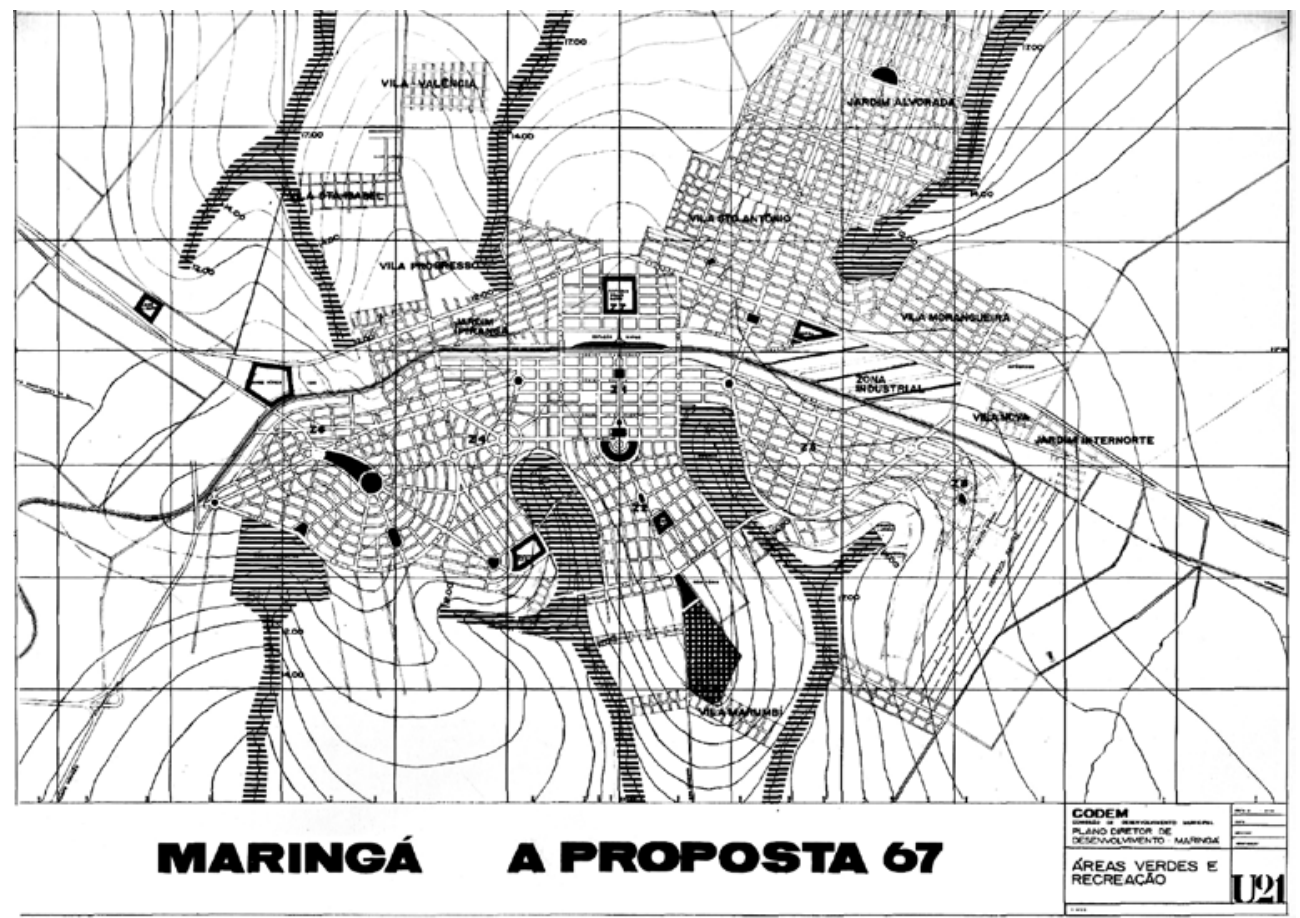

PAROUE E RESERVA FLORESTAL

::::::PENTRO UNNERSITANNO

Figura 2: Maringá - Plano Diretor de Desenvolvimento, 1967 - Áreas verdes e recreação Fonte: CODEM, 1967

Foi na década de 1970 que o crescimento de Maringá atingiu proporções de verdadeira explosão, como pode ser visto no Quadro 1. Com as transformações na base agrícola regional, derivadas da substituição de culturas e da modernização da agricultura, ocorreu uma transferência maciça de população da zona rural para os

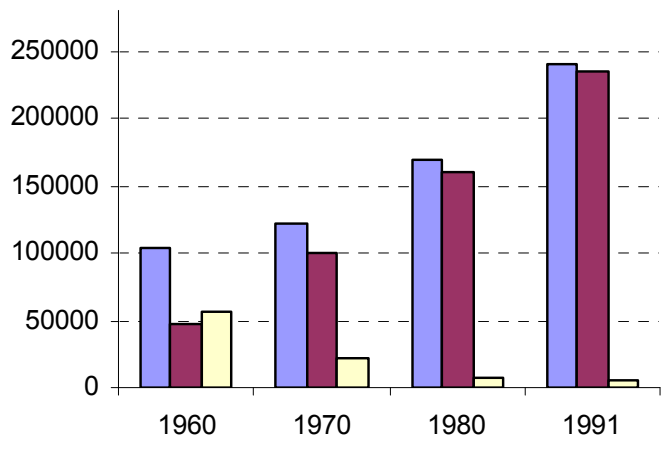

Quadro 1 - Maringá

Evolução da População

Fonte: MENEGUETTI, 2001

$\square$ POP. TOTAL $\square \%$ URBANA $\square \%$ RURAL 
centros urbanos de porte médio, como Maringá. Outro fator importante para esse acréscimo populacional foi a implantação da Universidade Estadual de Maringá, que atraiu professores, universitários e familiares (MARINGÁ, 2000).

O Plano de Diretrizes Viárias, de 1979, elaborado pela equipe de planejamento da prefeitura, liderada pelo arquiteto Nildo Ribeiro da Rocha, foi uma resposta a esse crescimento surpreendente. Esse plano, baseado em um levantamento aerofotogramétrico de toda a área do município, considerou as distorções entre o projeto original, as manchas urbanas dispersas e as restrições ambientais relativas ao relevo e corpos d'água (VILLALOBOS, 2003).

A área do perímetro urbano, de proporções então generosas (ela só foi ampliada em 2000) foi totalmente traçada em forma de diretrizes viárias que passavam a reger a aprovação de novos parcelamentos. Essas diretrizes podem ser observadas na Figura 3. Observe-se, ainda, que apenas a área mais escura da malha urbana estava efetivamente parcelada na época.

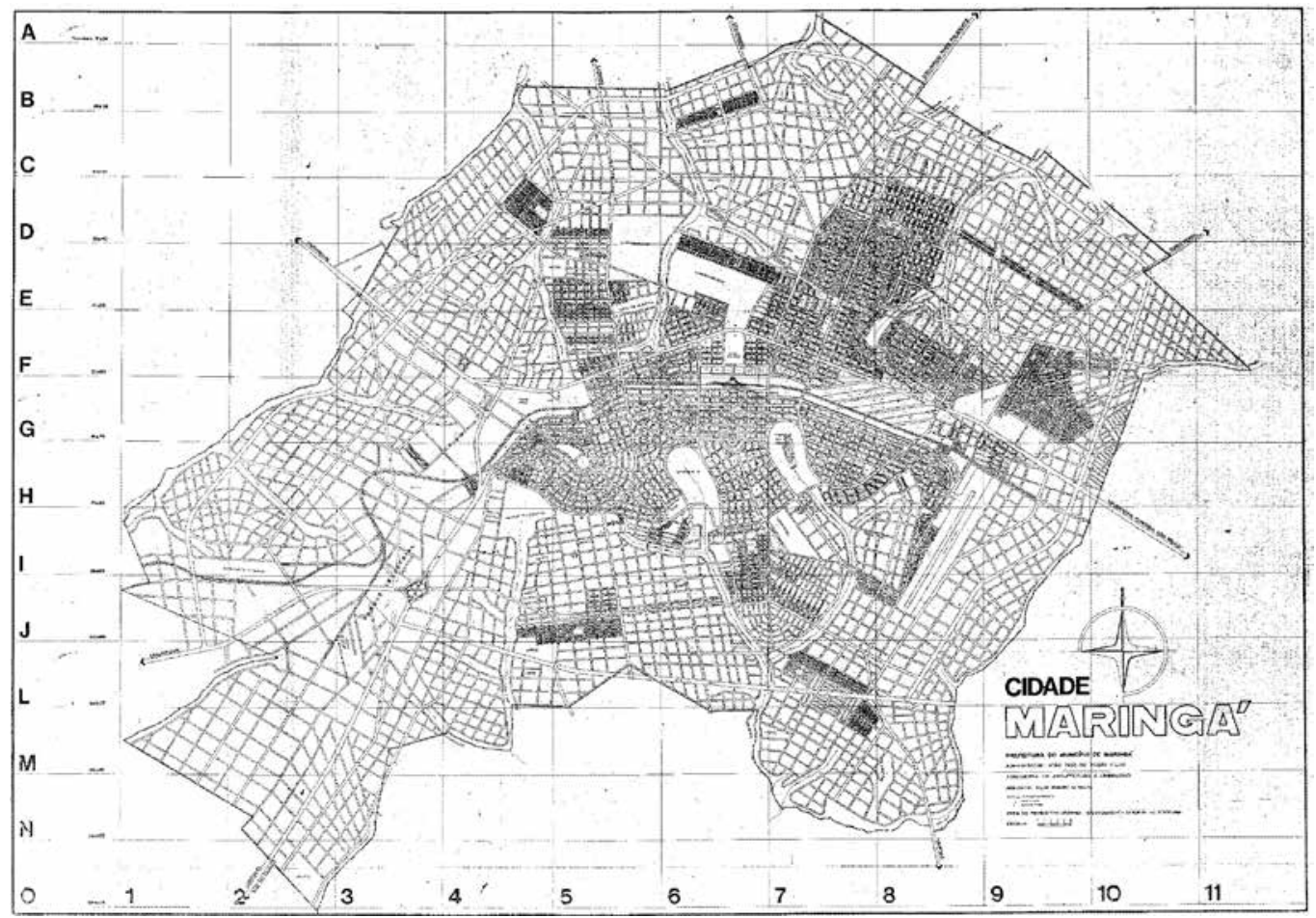

Figura 3: Maringá - Plano de Diretrizes Viárias, 1979

Fonte: MENEGUETTI, 2001

Em conformidade com a idéia das estruturas lineares do Plano Diretor de 1967, o Plano de Diretrizes Viárias de 1979 instituiu, de fato, os corredores verdes ao longo dos córregos, em uma distância mínima de 60 m de cada lado do rio, limitados por vias que se chamaram paisagísticas. Com efeito, não apenas se constituiriam os parques lineares, mas também se evidenciaria o sistema hídrico municipal como estrutura determinante da forma urbana e da paisagem dela resultante. Desse modo, conseguiu-se conectar 
as manchas urbanas que se encontravam desligadas do projeto original, conservar e proteger as áreas ambientalmente fragilizadas e, acima de tudo, oferecer condições de sustentabilidade às áreas de proteção do projeto original, permitindo a conexão entre áreas verdes. A conformação dos corredores verdes foi fundamental para que, ainda hoje, fosse possibilitada a implementação de um sistema de áreas livres com caráter ecológico.

Mas, com essa atitude, o plano reconfigurou a cidade com características completamente diversas daquelas as quais nortearam o plano original. Assim, o traçado retilíneo foi adotado, em razão direta e exclusiva da forma das parcelas de lotes rurais que cercavam o projeto original, de maneira a conciliar os interesses imobiliários e as facilidades de execução do arruamento proposto, como forma de fazer-se aceitar a proposta e viabilizar ligações importantes e definitivas.

A década de 1980 testemunhou o auge da verticalização urbana, notadamente no período 1984-1989. A situação econômica favorável, aliada à permissividade da lei vigente, transformou a paisagem do centro da cidade e da Zona 7, lindeira à universidade, o que acabou por tornar inadequada a infra-estrutura urbana, criando corredores altamente edificados em que o conforto urbano e a paisagem são altamente desfavorecidos.

Já nos anos 90 ocorreu uma dupla alteração no modelo de desenvolvimento da cidade, tendo-se verificado, por um lado, o aumento no ritmo de aprovação de novos loteamentos e, por outro, a queda no nível de densidade demográfica, que vinha se elevando progressivamente desde a fundação de Maringá. Isso significou um aumento da representatividade das habitações unifamiliares e bifamiliares, o que, novamente, vai modificar a cena urbana.

O Plano Diretor Integrado de Desenvolvimento de Maringá, o segundo plano diretor da cidade, foi aprovado em 1991 e substituído somente em 2006. Nesse período foram tantas as modificações da legislação urbanística e tamanha a ousadia do legislativo, que a relação entre planos e paisagem tornou-se desconexa, com uma grande participação dos interesses imobiliários.

O novo plano diretor, a despeito de desconsiderar as peculiaridades paisagísticas da cidade, englobando aspectos particulares em "macrozonas", incorpora preocupações ambientais, principalmente com relação aos corredores de biodiversidade e à proteção do manancial de abastecimento, mas de maneira geral e abrangente. Aprovado em outubro de 2006, ainda não foi efetivado em forma de nova legislação urbanística.

\section{CARACTERIZAÇÃO DOS ESPAÇOS LIVRES EXISTENTES}

Os espaços livres tendem a ser aqueles de maior vulnerabilidade no espaço urbano, visto serem constantemente interpretados como espaços ainda livres de edificação, ou seja, no aguardo de algum outro tipo de ocupação. Muitas vezes negligenciados pela gestão da cidade, tornam-se alvo da cobiça imobiliária e da submissão a outros sistemas, como o da circulação urbana, sucumbindo, muitas vezes, por falta de valorização de 
seus papéis determinantes. Maringá, apesar do pouco tempo de sua história, já possui exemplos dessa transformação dos espaços (MENEGUETTI, 2007).

A Figura 4 mostra a situação atual dos espaços livres da cidade de Maringá. Percebe-se que a maior parte desses espaços está concentrada dentro dos limites do projeto original, na área central. Nas áreas de expansão da malha urbana, principalmente ao norte do território, um grande número de rótulas viárias e os fundos de vale configuram os espaços dessa natureza, em conformidade com o plano viário de 1979. Por essa figura, comprova-se ainda que, na ampliação da cidade, não houve preocupação quanto à destinação de áreas para o uso do lazer, excetuando-se as áreas florestadas que tiveram sua ocupação proibida pelos órgãos ambientais e possibilitaram a implantação dos parques periféricos.

Quanto às praças, além daquelas decorrentes do projeto viário da cidade, outras foram projetadas apenas nos loteamentos aprovados até 1970. Na maior parte dos loteamentos posteriores a essa data, as áreas de doação para uso público foram restringidas a lotes para a implantação dos equipamentos urbanos, não sendo considerada a demanda de áreas de lazer e recreação (MENEGUETTI, 2001).

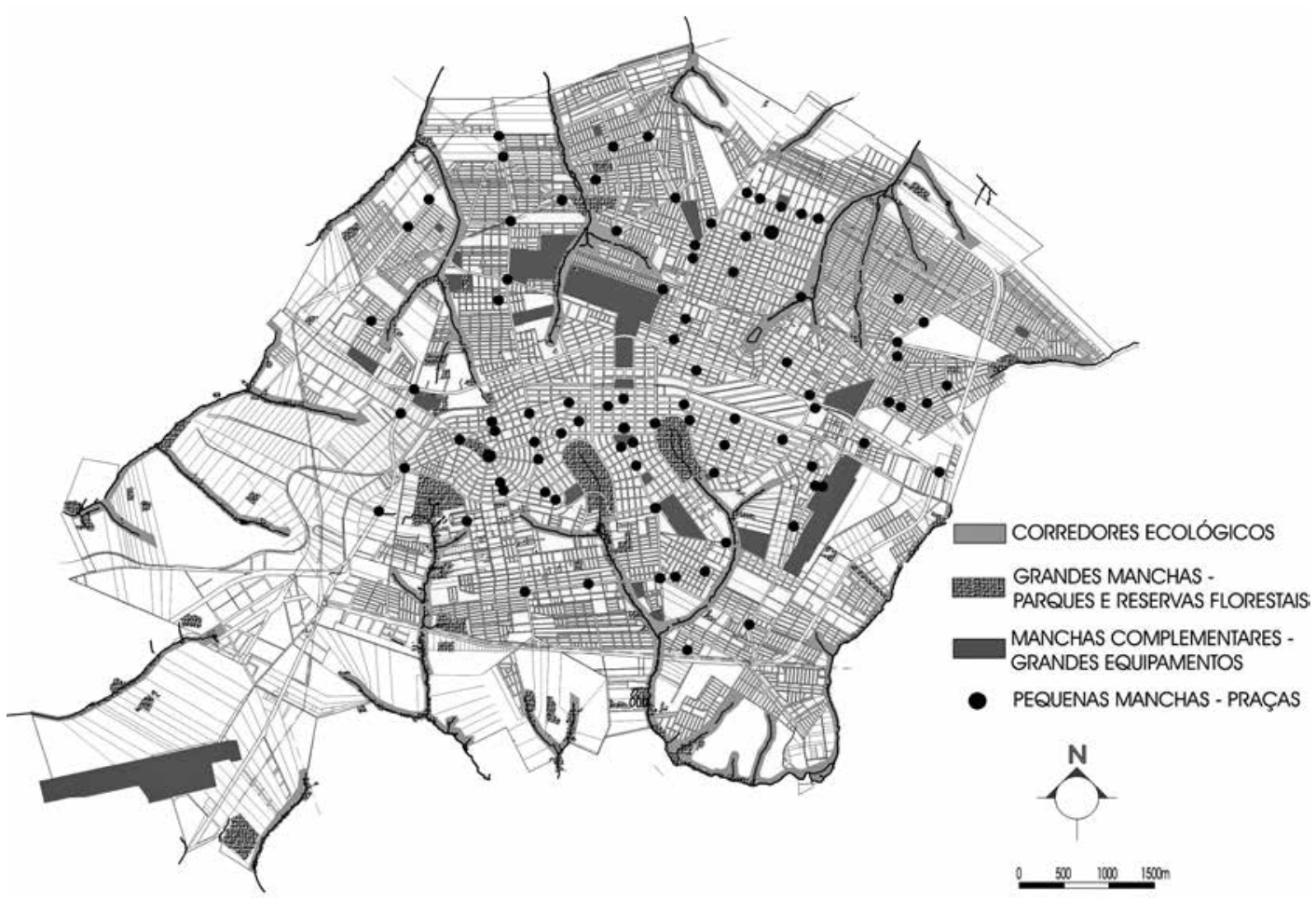

Figura 4: Maringá - Espaços livres - Situação atual

Crédito: Organização dos autores. Base: PMM, 2006

\section{Praças}

As praças mais significativas de Maringá continuam sendo aquelas previstas no plano original da cidade. Não só por sua história, mas pela forma, ambientação e manutenção dessas áreas. As áreas de expansão urbana têm espaços pouco apropriados 
ao lazer e ao convívio e, muitas vezes, sem a urbanização conveniente, nem chegam a ser consideravelmente ocupadas.

Dentre as praças originalmente previstas, a praça da Catedral e o Centro de Convivência Deputado Renato Celidônio continuam sendo as principais áreas verdes livres da cidade. Seu uso efetivo o comprova. De fato, essa grande área livre foi originalmente projetada para ser o ponto central da cidade. Entretanto, no anteprojeto de Macedo Vieira, as quadras periféricas seriam ocupadas por edificações em forma de crescent, de uso público, e a estação rodoviária e a igreja matriz flanqueariam essa praça de desenho eclético, cujo principal atrativo seriam as fontes luminosas. No projeto implantado, esses espaços foram substituídos por quatro quadras de uso comercial, sendo uma ocupada pelo Grande Hotel (em primeiro plano na Figura 5), de propriedade da companhia colonizadora, uma destinada à prefeitura e duas a órgãos públicos, sem restrições quanto à forma de ocupação.

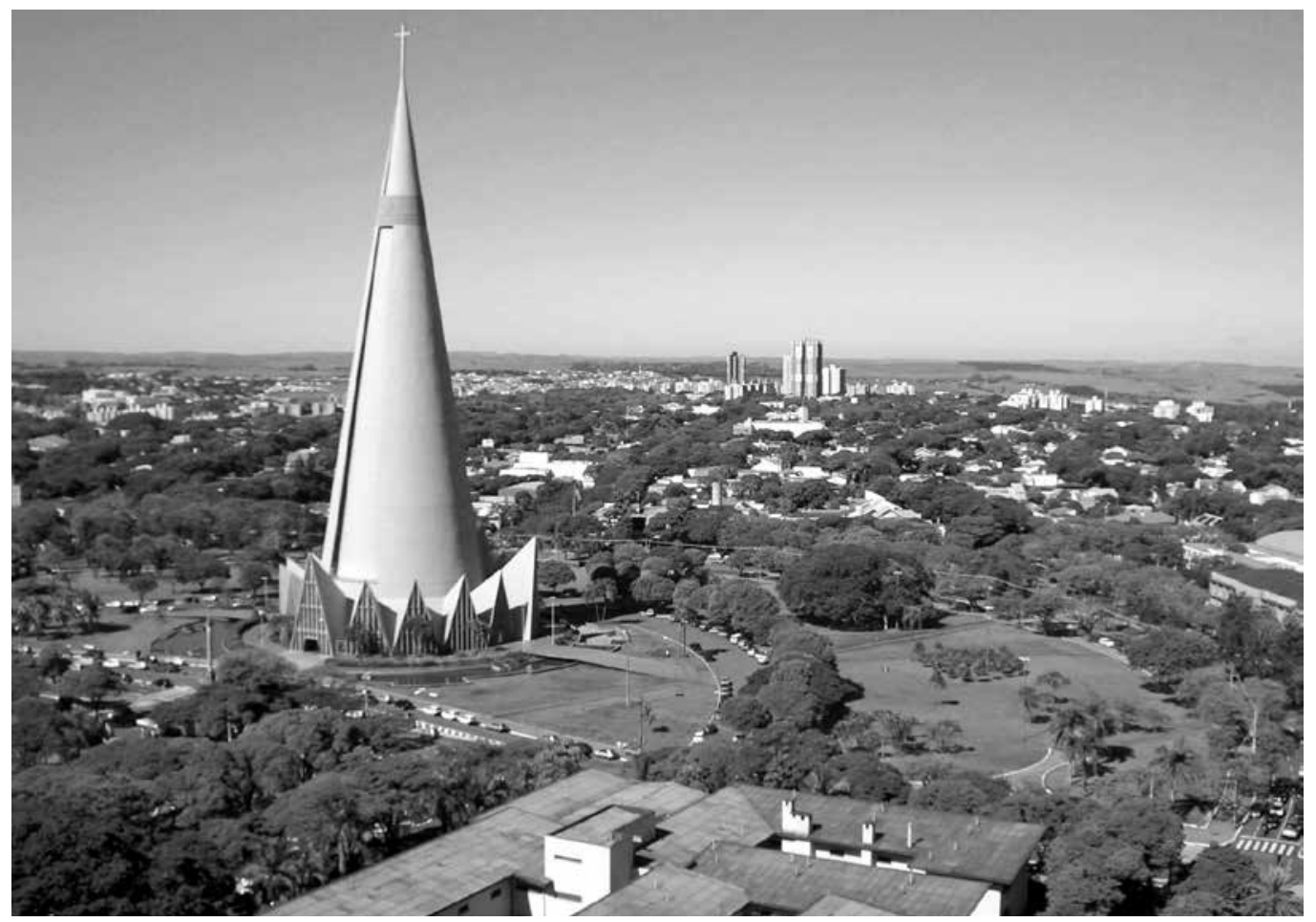

Figura 5: Maringá. Praça da Catedral Crédito: Foto dos autores, 2007

A exemplo da alteração radical da posição dos edifícios, a forma das praças tampouco foi mantida. Originalmente projetadas pelo arquiteto Augusto Bellucci, as praças de originais foram substituídas, em 1987, por um amplo calçadão denominado Centro de Convivência, incorporando as vias adjacentes (Figuras 8 e 9). Com isso se criou um grande espaço impermeabilizado cujas pequenas porções vegetadas ficam ilhadas em canteiros, pouco contribuindo para o conforto térmico ou absorção das águas pluviais. Entretanto, desde então, esse espaço acolheu uma festa beneficente que acontece com 
sucesso duas vezes por ano. $\bigcirc$ paisagismo em torno da Catedral, com espelhos d'água, fontes e grandes áreas gramadas, foi implantado em 1980.
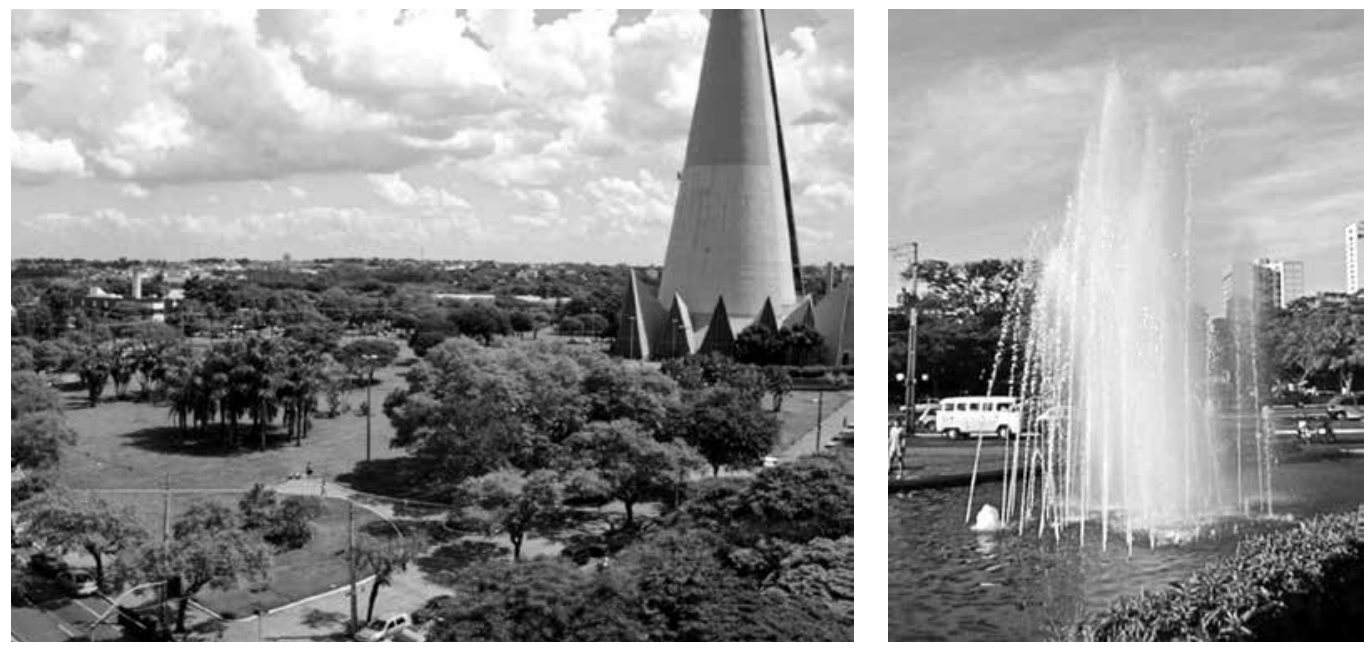

Figuras 6 e 7: Praça da Catedral, 2005 e 1998 Fonte: Acervo dos autores
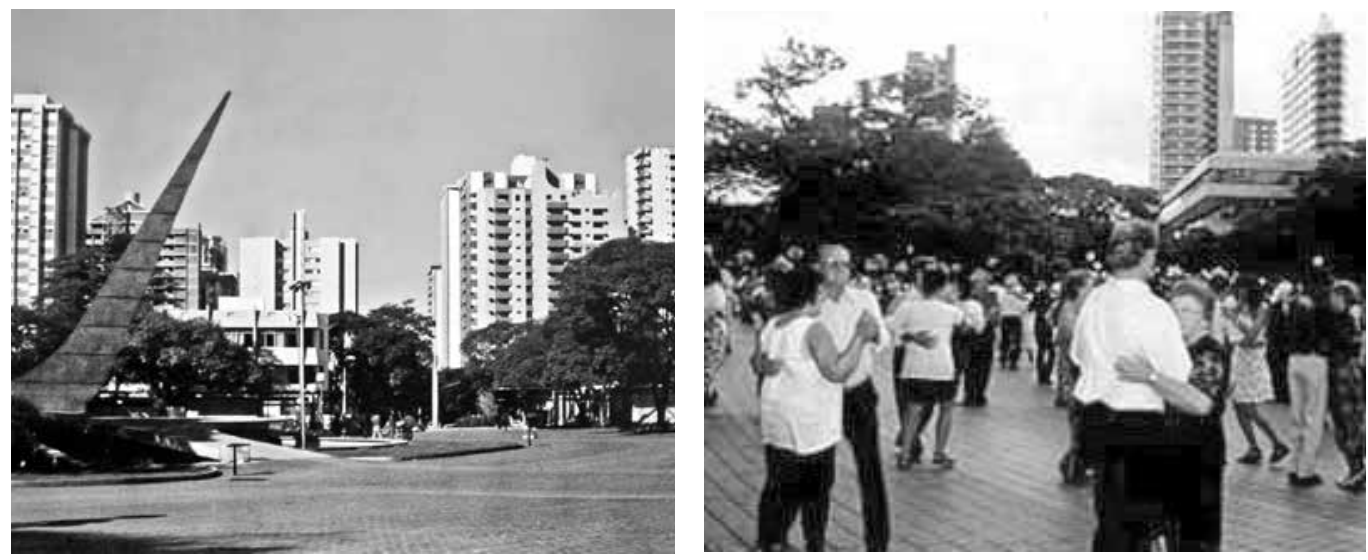

Figuras 8 e 9: Centro de Convivência Comunitária, 1994 (antiga praça D. Pedro II) Fonte: Prefeitura de Maringá

Outra área livre que se destaca no centro da cidade é a praça Napoleão Moreira da Silva. Sua configuração resultou do parcelamento da área central da cidade, de topografia plana, traçado ortogonal e quadras regulares. Sua localização junto da principal artéria da cidade - a avenida Brasil - propiciou a instalação da primeira estação rodoviária, contrariando o anteprojeto de Macedo Vieira. Localizada no ponto mais movimentado da área comercial, cercada por bancos, comércios de grande porte como Pernambucanas e Riachuelo, essa praça é alvo de todo tipo de uso, inclusive noturno. Ela tem sido ocupada por diversos equipamentos, de creche a terminal de transporte urbano, de quiosques à casa de Papai Noel, e com isso seu projeto tem sido paulatinamente modificado. 
Com $11.520 \mathrm{~m}^{2}$, ela foi a primeira praça construída na cidade, nela encontravamse as pequenas instalações da rodoviária e, ao seu redor, havia os pontos de carroças e charretes a servirem como táxis (DE ANGELIS, 2000). Doada pela Companhia à prefeitura, arborizada com espécies nativas da região, foi alvo da discórdia entre a empresa colonizadora e a prefeitura, que exterminou as árvores e implantou a estação rodoviária em outro local, no eixo principal da cidade. A companhia, então, urbanizou a praça de acordo com o projeto desenvolvido pelo arquiteto Augusto Bellucci. Daí seu desenho sofisticado, marcadamente modernista, a incluir espécies vegetais de valor botânico, como uma falsa seringueira - Ficus elastica - de enormes dimensões e palmeiras imperiais adultas - Roystonea spp. -, além de outras espécies nativas (Figuras 10 e 11).
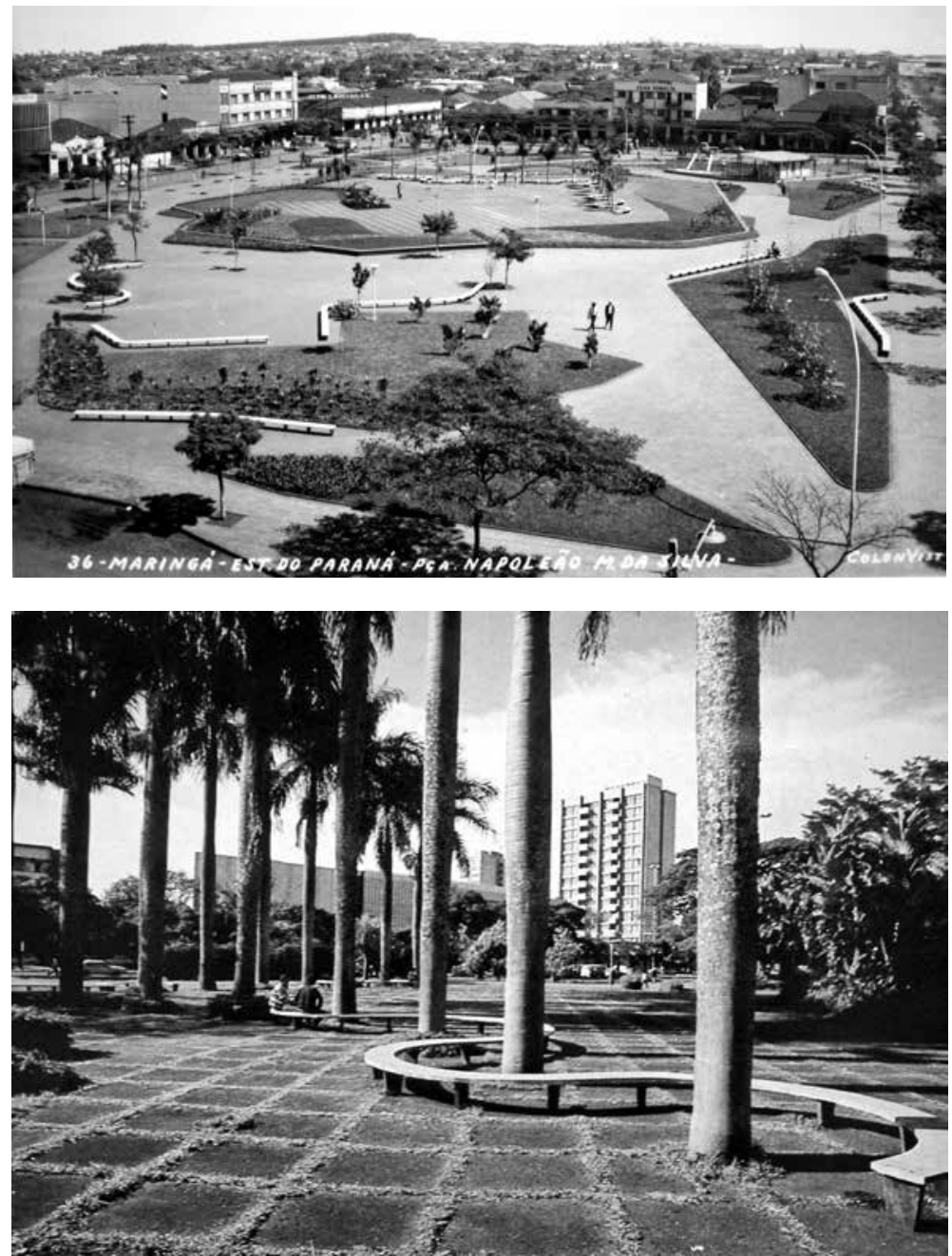

Figura 10: Praça Napoleão Moreira da Silva, 1968 Fonte: Prefeitura de Maringá
Figura 11: Praça Napoleão Moreira da Silva. Detalhe da área elevada Fonte: Prefeitura de Maringá

Já a praça Raposo Tavares faz o contraponto com a praça da Catedral, na outra extremidade do "eixo monumental" da cidade. Com a implantação da Rodoviária na década de 1950, essa praça recebeu uma "fonte luminosa" e tornou-se o ponto de encontro da população. Na década de 1970 ela foi reformada, e então foram implantados os canteiros elevados, os bancos individuais e um pequeno anfiteatro denominado 
"Templo da Bíblia", por abrigar pastores em pregação e seus fiéis. Atualmente, com a relocação do terminal rodoviário e o abandono da edificação da antiga rodoviária,

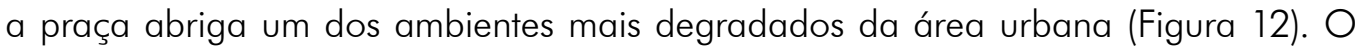
comércio informal compete com os pregadores, prostitutas e desocupados, além do tráfico e consumo de drogas e outros delitos.

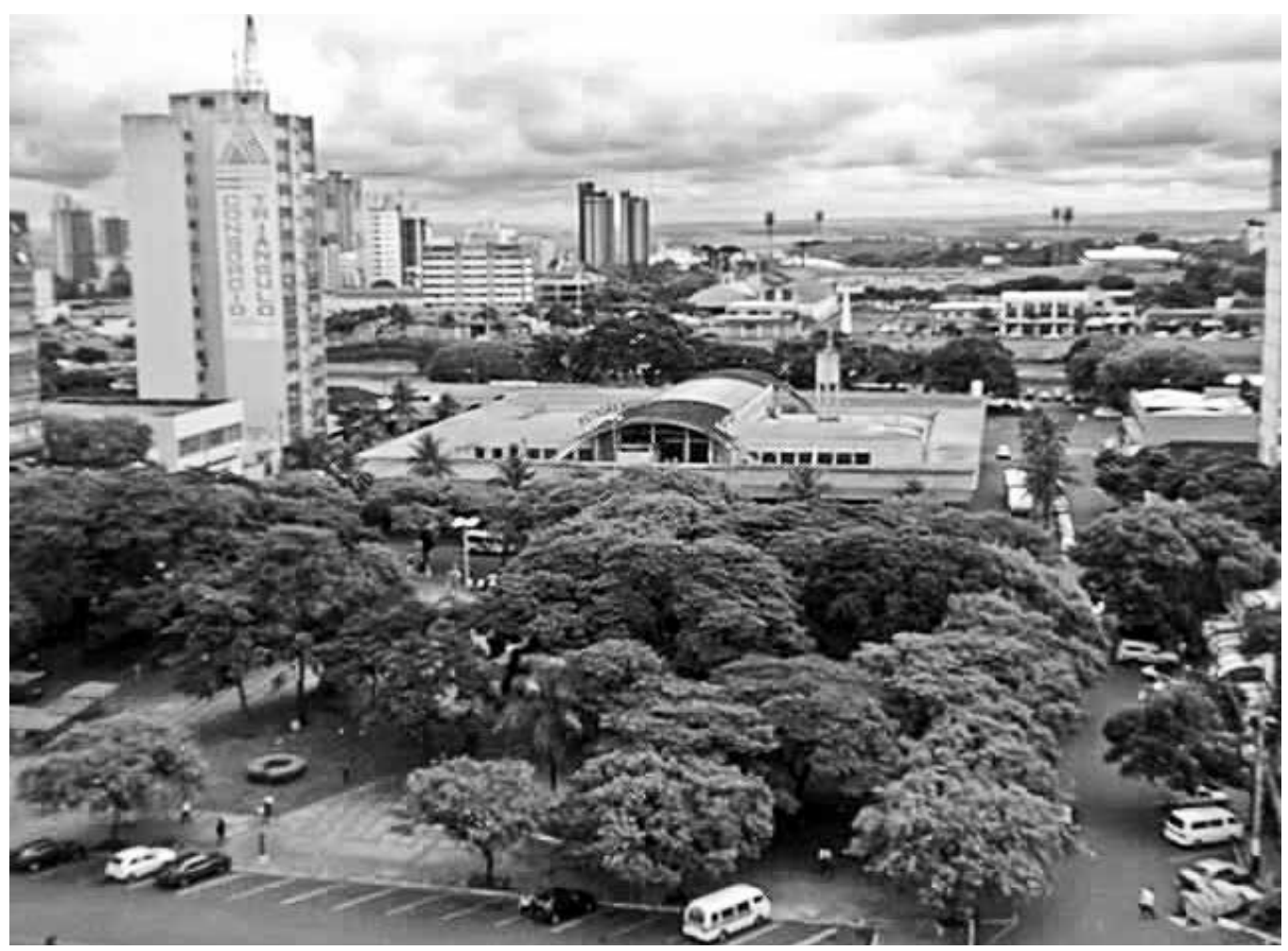

Figura 12: Praça Raposo Tavares, 2001

Fonte: Acervo dos autores

As demais praças do projeto original da cidade receberam modificações de menor grau. Percebe-se que a urbanização daquelas, realizadas, principalmente, durante as décadas de 1960 e 1970, seguiu os pressupostos do período moderno, com a inclusão maciça do lazer ativo (ROBBA; MACEDO, 2002). Do mesmo modo foram urbanizadas algumas praças das áreas mais recentes da cidade. Assim, essas praças, em geral, assumiram a condição de espaço de recreação diversificado, atendendo às necessidades de lazer de uma grande faixa populacional (Figuras 13 e 14).

Junto do centro da cidade, duas grandes áreas de lazer e esportes se destacam: o campus da Universidade Estadual de Maringá e a Vila Olímpica. A primeira, por apresentar baixa densidade de ocupação, grandes áreas verdes, esporte, recreação; a segunda, pelo estádio, ginásio coberto, quadras, piscinas e velódromo. Aí se concentra grande número de pessoas em eventos freqüentes.

Por fim, é preciso relatar o caso particular do Novo Centro de Maringá. $\bigcirc$ vazio deixado pelo rebaixamento da via férrea e o deslocamento do pátio de manobras 

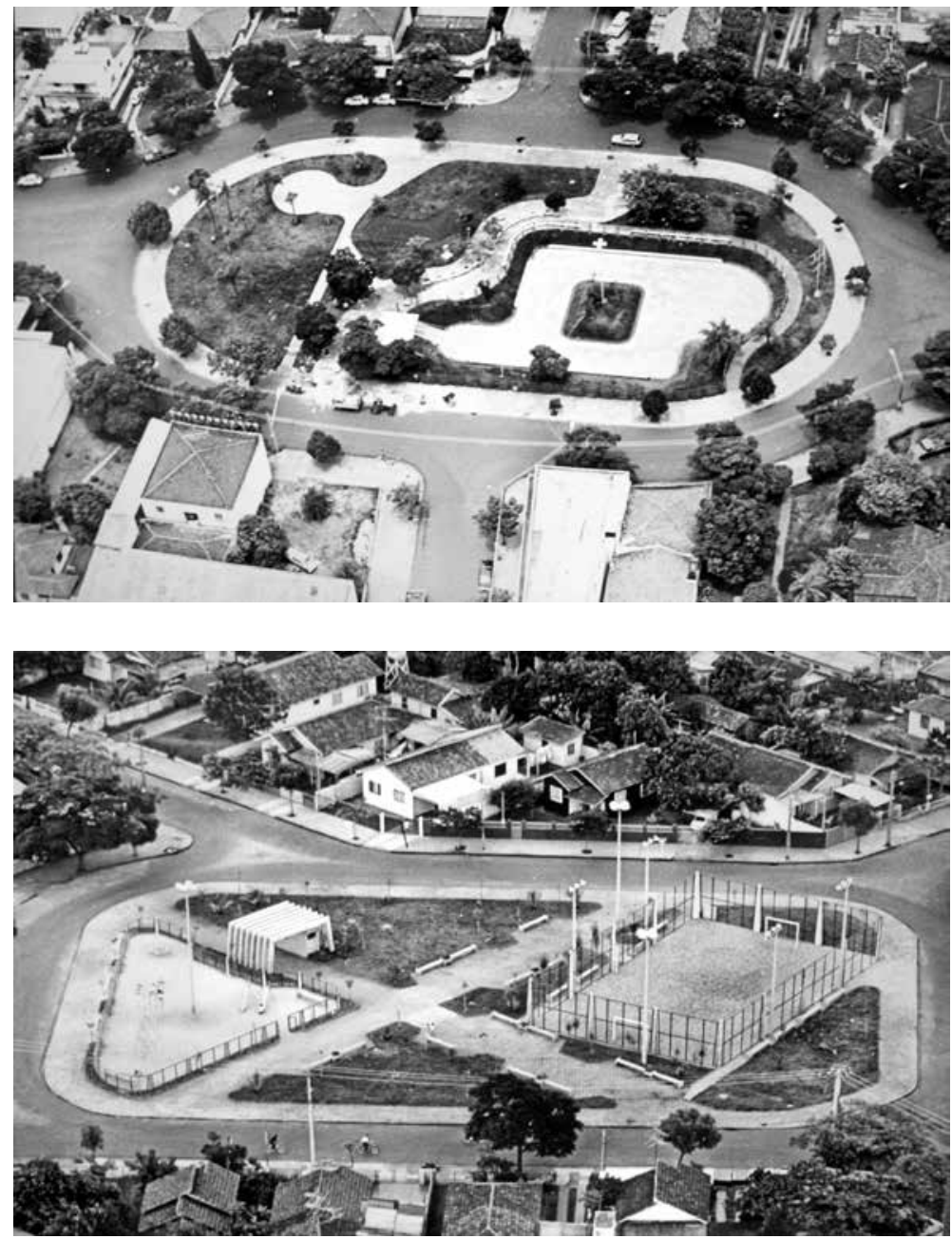

Figura 13:

Praça Pedro Álvares Cabral, 1980

Fonte: Prefeitura de

Maringá
Figura 74:

Praça Oswaldo Vieira, 1980 Fonte: Prefeitura de Maringá

chegou a ser cogitado como destino de uma grande área pública de lazer e cultura no centro da cidade.

Com o predominante crescimento urbano na zona norte da cidade e a localização, nessa área, de atividades geradoras de grandes fluxos de tráfego, como a Universidade Estadual de Maringá, o projeto original de Maringá passou a apresentar um grande seccionamento. Os eixos de tráfego pesado deixaram de ser perimetrais e incrementaram o fluxo urbano no sentido norte-sul (Figura 15), sobrepujando os eixos leste-oeste que determinavam o partido urbanístico linear da cidade. Havia, ainda, a barreira física causada pelo pátio de manobras da ferrovia e a própria linha férrea, reforçada pela localização das áreas industriais e de armazéns ao longo desse eixo, e a barreira psicológica causada pela degradação que esses usos causavam ao entorno (MENEGUETTI, 2001).

Com essa área desocupada, o poder público municipal apresentou um projeto global de urbanização, denominado Projeto Ágora. Encomendado pela administração municipal ao arquiteto Oscar Niemeyer, o projeto previa edifícios isolados sobre um grande subsolo de dois pavimentos de garagem, sendo um privado e outro público, 


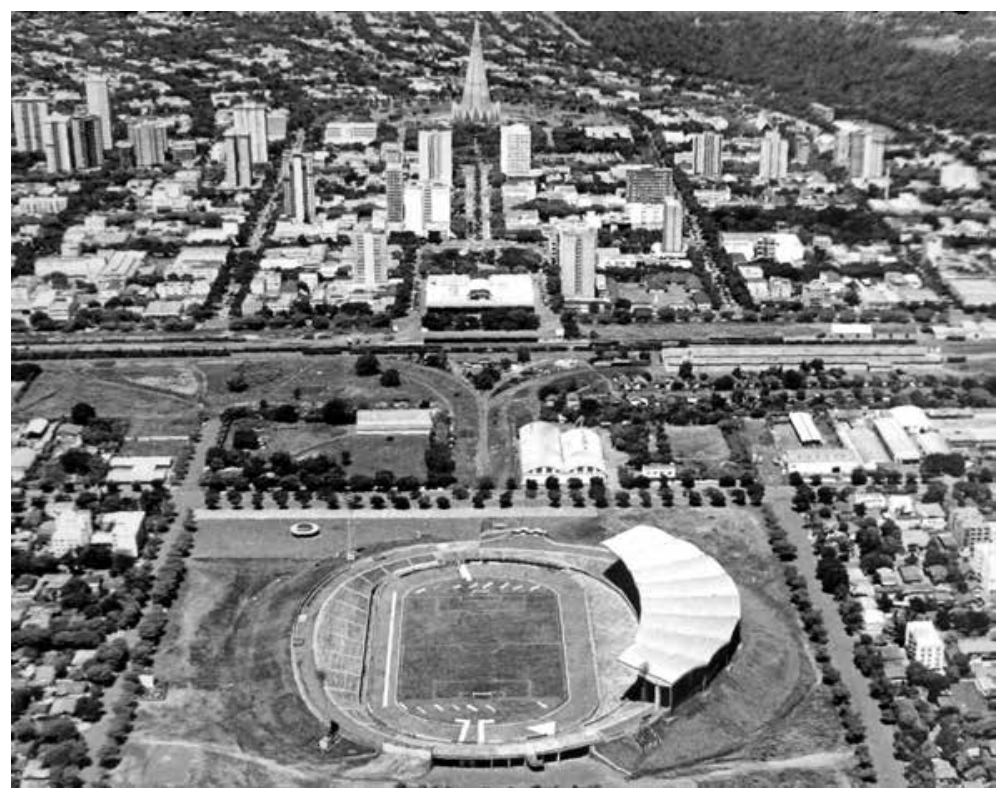

Figura 15:

O eixo norte-sul - em primeiro plano - e estádio municipal; a linha férrea ao centro e a catedral ao fundo Fonte: Prefeitura de Maringá, 1980

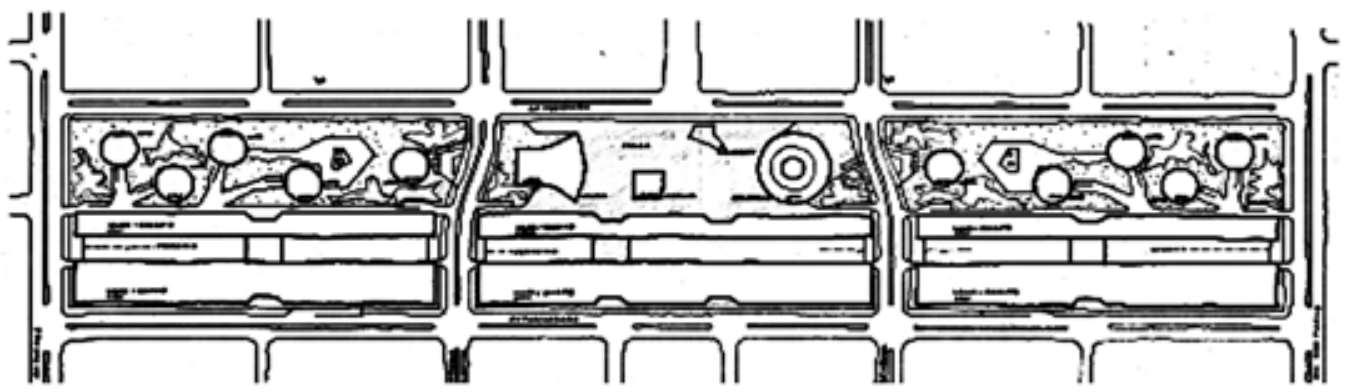

Figura 16: Novo Centro - Projeto Ágora Fonte: MENEGUETTI, 2001

a linha férrea rebaixada a céu aberto e edifícios comerciais ao longo dela (Figura 16). A área livre onde se inseriam os edifícios isolados deveria ser uma ágora, a grande praça que dava nome ao projeto.

A obra deveria ser viabilizada como um todo, o que se tornou impraticável economicamente. Mas a solução de individualização dos edifícios, com a obrigatoriedade da construção dentro dos moldes propostos, não se mostrou atrativa para os investidores, o que obrigou à deturpação do projeto. Ainda assim apenas alguns lotes foram comercializados, basicamente a troco de dívidas da prefeitura.

Diante dessa situação desfavorável à urbanização da área, a prefeitura optou por desenvolver outro projeto de urbanização, calcado na realidade regional e com o firme propósito de impulsionar as obras efetivamente. Implantou-se, então, o Plano Diretor do Novo Centro de Maringá, o qual contemplava o rebaixamento do leito da ferrovia na área central da cidade, com túnel de dimensões suficientes para a implantação futura do transporte de massa metropolitano e a previsão para um terminal intermodal subterrâneo. O Plano ainda contemplava a abertura de uma rua sobre a laje de cobertura 
do túnel, o prolongamento de certas ruas transversais por sobre a área do antigo pátio, a criação de um amplo espaço de uso público no ponto médio da gleba, destinado a atividades culturais, recreativas e de lazer da comunidade e, por fim, o parcelamento da área remanescente e a venda dos lotes resultantes para custear todas essas obras de engenharia e urbanização (Figura 17).

O rebaixamento do leito da ferrovia iniciou-se em 1995, com a conclusão do túnel no trecho entre as avenidas São Paulo e Paraná em 1996. No final de 1999 foi completado o túnel no trecho entre as avenidas São Paulo e Pedro Taques, possibilitando a implantação da rua projetada sobre sua laje de cobertura e a complementação das obras de urbanização no terreno, necessárias à sua ocupação (MENEGUETTI, 2001).

Em 2000 um movimento de entidades solicitou à prefeitura que toda a área central dessa gleba permanecesse como área livre de uso público, pois os lotes que haviam sido comercializados junto da praça projetada não haviam ainda sido ocupados. Apesar do compromisso assumido, o proprietário edificou, inviabilizando a permanência de um espaço com dimensões mais favoráveis à densa ocupação futura dos lotes lindeiros. $\bigcirc$ destino dessa área ainda não está certo e a presença de uma grande área verde livre não parece ser a prioridade do poder público. Até o momento, as quadras adjacentes estão sendo ocupadas por edifícios de uso misto, em parcelamento convencional, sem definição do uso e da ocupação da área central.

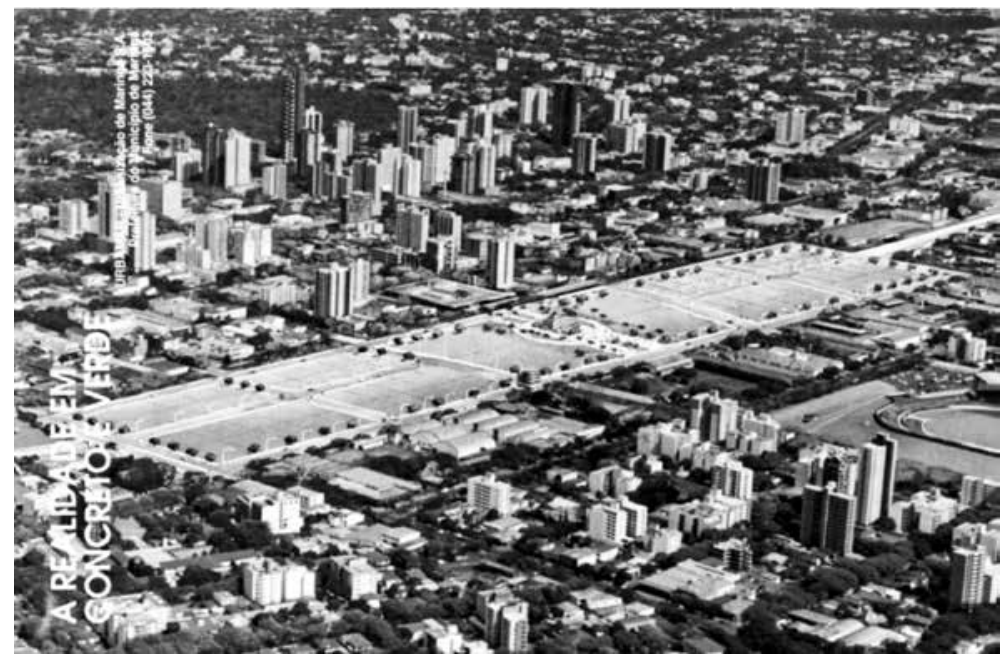

Figura 17:

Plano Diretor do novo centro Fonte: MENEGUETTI, 2001

\section{Parques e reservas florestais}

Os parques e reservas florestais existentes em Maringá encontram-se em situação bastante precária. A fragmentação do ecossistema de floresta causou um decréscimo na riqueza das espécies e mudanças na estrutura e composição ecológica. Essas grandes manchas sofrem uma intensa pressão pela urbanização do entorno e pela falta de reconhecimento de suas funções ambientais. Tornam-se espaços negligenciados, cuja preservação demanda policiamento constante. 
No patrimônio ambiental da cidade destacam-se os dois parques centrais: o Parque do Ingá e o Parque dos Pioneiros. Conformados pelo plano original, são os "pulmões" formados por remanescentes de mata nativa, projetados por Macedo Vieira. Esses parques se conectam por corredores formados pelos córregos ao sul, que se tornam rotas de dispersão natural.

Antes conhecido como Bosque 1, o Parque do Ingá recebeu essa denominação em função da abundância da planta do gênero ingá. Esse parque (Figura 18) foi urbanizado a partir de 1969, com a implementação da recreação e a viabilização da conservação do parque, a fim de integrar essa área ao cotidiano da população. $\bigcirc$ parque dispõe de trilhas para caminhadas, lago, um pequeno zoológico (que está sendo desativado) e outras infra-estruturas de lazer. Em 1972, com a visita do príncipe japonês Akihito e da princesa Michiko à cidade, o parque ganhou um pequeno jardim japonês (Figura 19).

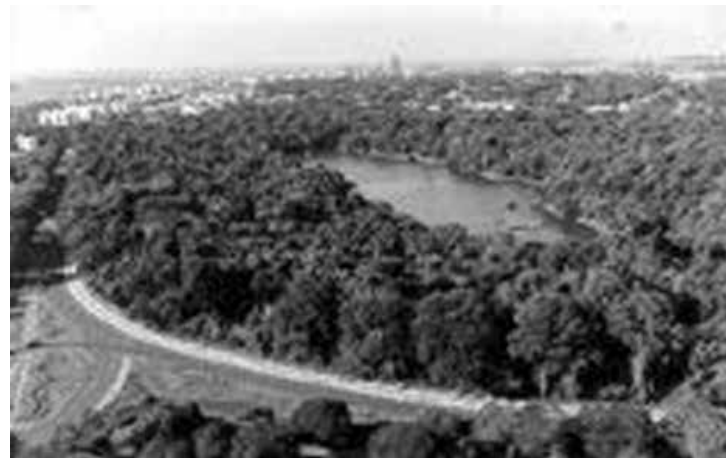

Figura 18: Parque do Ingá, 1997

Fonte: Prefeitura de Maringá

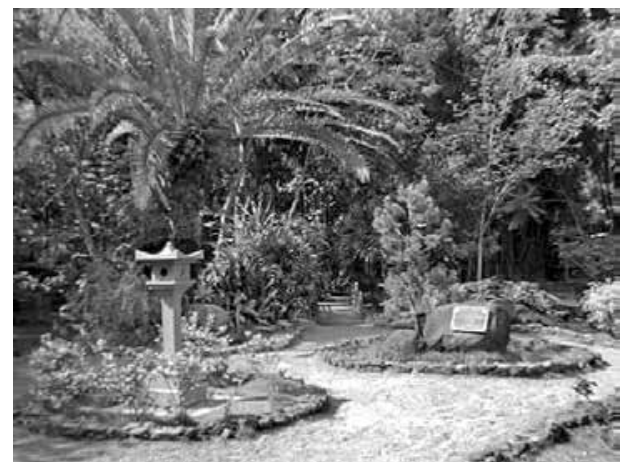

Figura 19: Parque do Ingá, jardim japonês Fonte: Prefeitura de Maringá

Devido ao excesso de impermeabilização do solo no centro da cidade, ao rebaixamento do lençol subterrâneo e à falta de aeração, o lago, principal atrativo do parque, está sofrendo degradação progressiva. Apesar dessa situação, o Parque do Ingá é rico em espécies animais soltas, como: sagüis, quatis, cutias, patos e gambás.

A outra área de reserva proveniente do projeto de Macedo Vieira, o Parque Florestal dos Pioneiros, anteriormente denominado Bosque 2, configura-se como uma bacia de recepção das águas drenadas pelo Córrego Cleópatra - sofreu os primeiros desmatamentos em 1976, quando da construção, na porção norte, de uma pista de motocross e, na porção sul, a abertura da via perimetral sul. A pista foi desativada rapidamente, em função da degradação que provocou no período e do Plano de Manejo, elaborado em 1993, que previa a retirada de toda e qualquer ocupação do lugar, incluindo a casa do vigia. Contudo, contrariando o plano, o parque recebeu, em 1998, uma edificação de uso público-privado financiada pelo governo estadual, denominada "Usina do Conhecimento", cuja função inespecífica foi facilmente justificada como vinculada às atividades do parque. Assim, mesmo tendo sido declarado Área de Preservação Permanente em 1982, o bosque sofreu inúmeras tentativas de ocupação. 


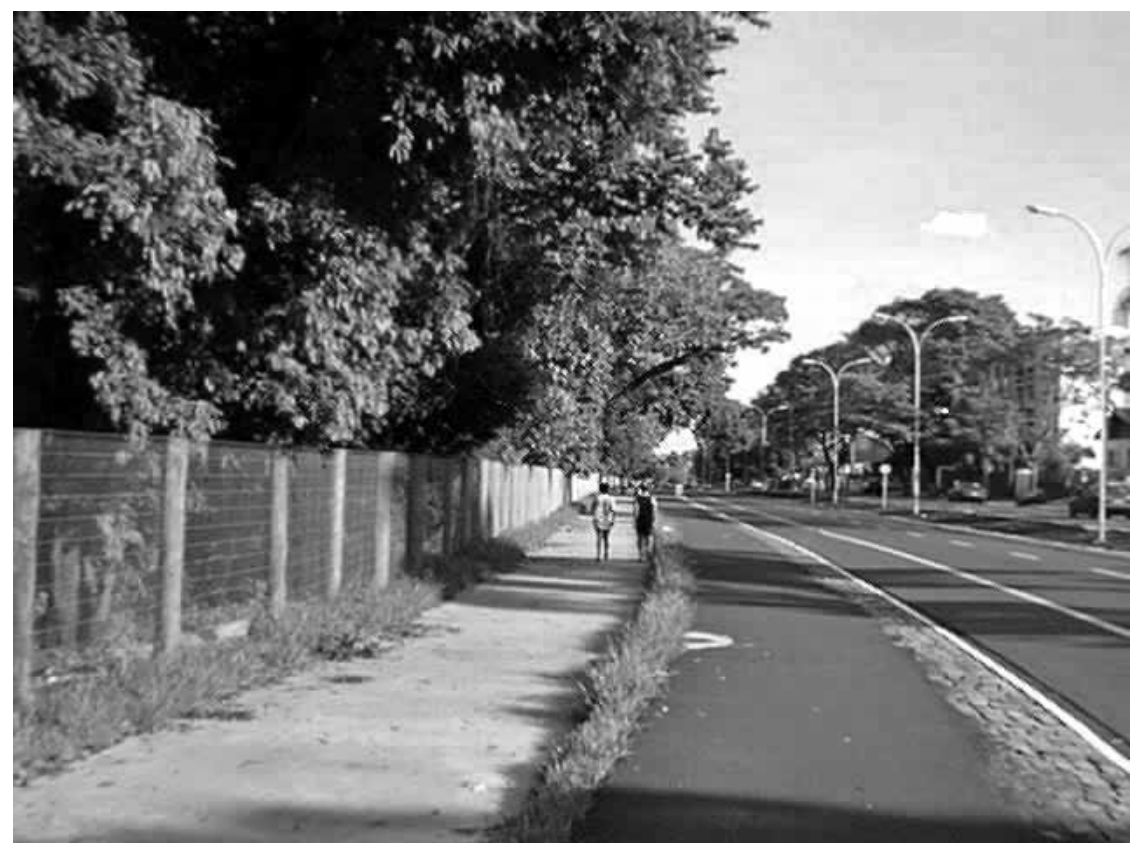

Figura 20:

Parque Florestal dos Pioneiros, 2000

Fonte: MENEGUETTI, 2007

O bosque, embora já despojado de muitas espécies vegetais mais valiosas (como a peroba), ainda apresenta expressivos representantes da flora nativa, além da presença de animais como lagartos e macacos-prego, que encantam os pedestres na calçada e os visitantes.

Uma terceira grande área verde foi incorporada ao plano original da cidade: o Horto Florestal, apenas mencionado no último estudo de Macedo Vieira. Essa área de cerca de 37 hectares é uma reserva que ainda hoje conserva a mata nativa intacta, com exemplares seculares de gurucaias, cedros, marfins, alecrins, paus-d'alhos, perobas e figueiras (RECCO, 2005). $\bigcirc$ Horto possuía estrutura para produção de mudas visando à arborização das cidades fundadas pela CMNP e ajardinamento de praças e canteiros. Uma clareira e seu pequeno lago eram, então, usados para recreação. De propriedade da CMNP, o horto entrou em declínio com a saída dessa empresa da cidade, transformando-se em uma grande área abandonada e fechada para o uso público.

Além desses três parques, era também parte do projeto original da cidade o Bosque das Grevíleas. Este, de $44.000 m^{2}$ de reflorestamento de uma só espécie - a grevílea - possui uso, principalmente em seu entorno, para caminhadas da população da vizinhança. Os demais parques ou reservas, com exceção do Parque Alfredo Nyffeller, são remanescentes florestais preservados posteriormente. Apesar de receberem a conotação de parques, a apropriação dos mesmos ainda é precária, pois poucos receberam algum tipo de intervenção.

O Parque Alfredo Werner Nyffeller, criado para a proteção da nascente do córrego em um parcelamento da década de 1960, após anos de ocupação como depósito de resíduos sólidos e em progressivo processo de erosão, foi recuperado em 1988 como área de lazer (Figura 22). Abriga um lago artificial, formado pelo represamento do ribeirão Morangueiro, e equipamentos de recreação e lazer. 


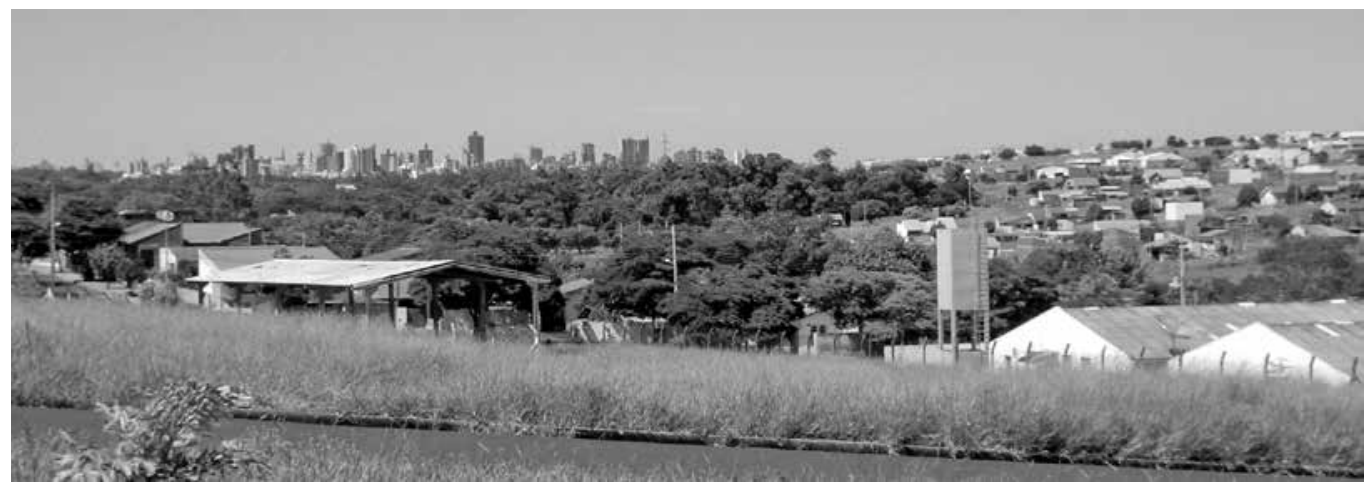

Figura 21: Parque Florestal das Palmeiras, ao centro, e Parque do Jardim Imperial, ao fundo Fonte: MENEGUETTI, 2007

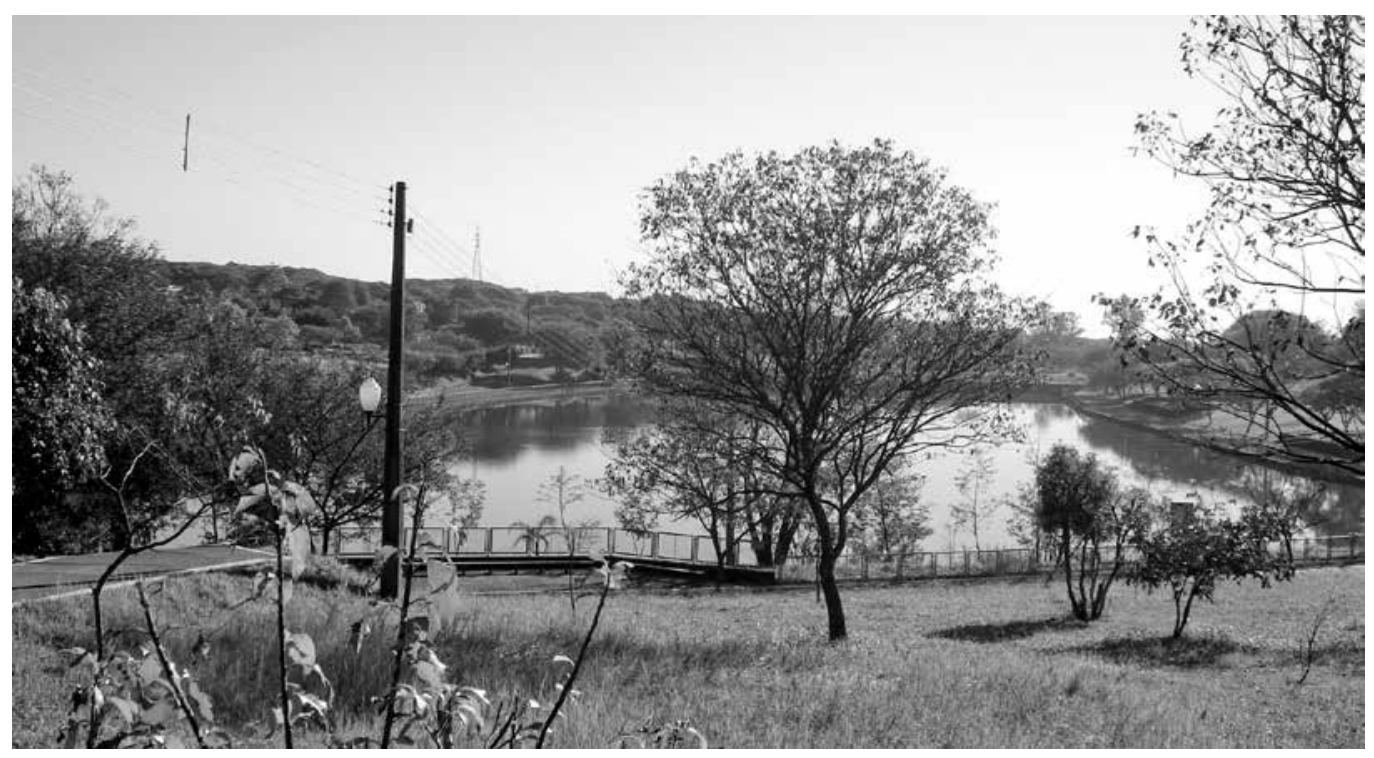

Figura 22: Parque Alfredo Werner Nyffeller Crédito: Foto dos autores, 2008

\section{Fundos de vale}

Na cidade de Maringá, os corredores verdes mais evidentes são os fundos de vale, formados pelas áreas de preservação junto dos corpos d'água que cortam a área urbana, projetadas no Plano de Diretrizes Viárias de 1979. Esses fundos de vale conectam as principais manchas verdes (parques e reservas), desempenhando um papel vital na sustentabilidade ambiental. A proposta de criação desses parques lineares para a proteção dos córregos possibilitou a estruturação do sistema tal como ele se encontra atualmente (MENEGUETTI, 2007).

Mas a ocupação ao longo desses corredores é bastante desigual. Isso ocorre porque, ao longo da urbanização da cidade, as gestões públicas adotaram diferentes medidas no recebimento das áreas dos loteamentos destinadas a equipamentos comunitários e públicos. Enquanto em determinadas épocas foram aceitos os fundos de vale como 


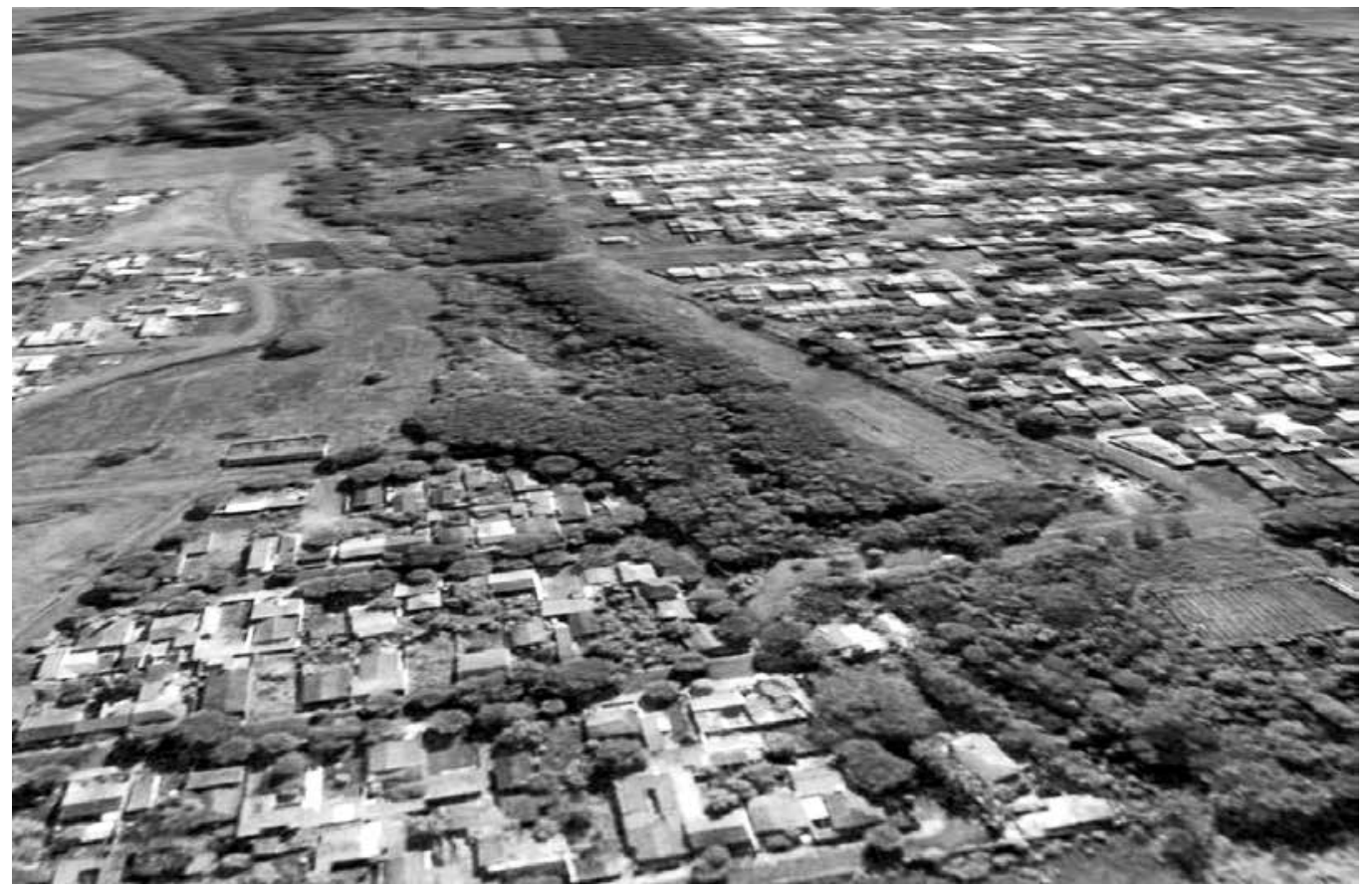

Figura 23: Corredor formado pelo fundo de vale do córrego Nazareth, 2006

Fonte: GoogleEarth

parte das áreas doadas ao município para equipamentos comunitários, em outros períodos essas áreas passaram a ser vendidas como chácaras, com restrição de uso da faixa lindeira ao rio.

Dessa forma, atualmente é muito difícil encontrar, nos $70 \mathrm{~km}$ de fundos de vale que cortam a malha urbana, trechos em que ambas as margens pertençam à municipalidade, de modo a viabilizar a formação dos parques destinados à recreação e lazer da população. Ao contrário, o que se vê são áreas fragmentadas, sem possibilidade de utilização racional e, por serem numerosas, demandam recursos para sua conservação superiores à capacidade financeira da prefeitura, estando sujeitas a invasões e à degradação ambiental, fato a comprometer o cumprimento da finalidade para a qual foram criadas. Por isso, esses fundos de vale não chegam, efetivamente, a formar os parques lineares que protegeriam as nascentes e mananciais.

\section{CONSIDERAÇÕES FINAIS}

Com base nessas colocações, nota-se que a cidade de Maringá apresentava, já em sua origem, qualidades paisagísticas as quais puderam fazer frente à grande expansão urbana característica de sua evolução.

A grande proporção de áreas livres, praças e parques, a generosidade na dimensão de lotes e vias e as peculiaridades de seu desenho urbano são, até hoje, diferenciais que qualificam a cidade. Em sua expansão, no entanto, esses elementos não foram repetidos. É facilmente percebida a desigual distribuição dos espaços livres na malha 
urbana; as praças e os parques melhor urbanizados e mais apropriados são ainda aqueles vinculados ao projeto original.

processo de regulação da produção do espaço urbano, se não repetiu as qualidades iniciais, teve dois momentos importantes, nos planos de 1967 e 1979, quando gerou os corredores verdes ao longo dos rios e permitiu, aos espaços livres, sua conexão e conseqüente possibilidade de formação de um sistema interconectado.

No entanto, a despeito dessa potencialidade, os espaços livres da cidade não contam com um reconhecimento pela diversidade de funções que poderiam desempenhar, sendo mantidos em condições bastante precárias. Nos novos parcelamentos tampouco são criados espaços livres adequados. $\bigcirc$ entendimento desses espaços como um sistema, ou ainda, uma estrutura, só aconteceu recentemente, em Meneguetti (2007).

A implementação de um modelo de gestão para o sistema como um todo e para os espaços livres individualmente poderia torná-los uma estrutura condizente com as qualidades urbanas do projeto original.

\section{Bibliografia}

CODEM - Comissão de Desenvolvimento Municipal. Plano Diretor de Desenvolvimento Maringá. Curitiba: Prefeitura, 1967.

DE ANGELIS, Bruno Luiz Domingos. A praça no contexto das cidades - O caso de Maringá - PR. 2000. Tese (Doutorado em Geografia) - Faculdade de Filosofia, Letras e Ciências Humanas, Universidade de São Paulo, São Paulo, 2000.

MARINGÁ (cidade). Plano Diretor de Desenvolvimento. Maringá: PMM, 2000.

MC HARG, I. L. Desing with nature. Nova York: John Willey \& Sons, 1992.

MENEGUETTI, K. S. Desenho urbano e qualidade de vida - O caso de Maringá - Pr. 2001. Dissertação (Mestrado em Geografia) - Universidade Estadual de Maringá, Maringá-PR, 2001.

De cidade jardim a cidade sustentável. Potencialidades para uma estrutura ecológica urbana em Maringá - Pr. 2007. Tese (Doutorado) - Faculdade de Arquitetura e Urbanismo, Universidade de São Paulo, São Paulo, 2007.

RECCO, R. À sombra dos ipês da minha terra. Londrina: Midiograf, 2005.

REGO, R. L.; MENEGUETTI, K. S. The construction of the urban form: The design of new cities in Brazil as part of an agriculture development business. In: INTERNATIONAL SEMINAR ON URBAN FORM, 2005, Londres. Proceedings... Londres, 2005.

REGO, R. L. et al. Reconstruindo a forma urbana: Uma análise do desenho das principais cidades da Companhia de Terras Norte do Paraná. Acta Scientiarum, Paraná, v. 26, n. 2, p. 141-150, 2004.

ROBBA, F.; MACEDO, S. S. Praças brasileiras. Public squares in Brazil. São Paulo: Edusp/Imprensa Oficial do Estado, 2002.

STEINKE, R. Ruas curvas versus ruas retas: A trajetória do urbanista Jorge de Macedo Vieira. Maringá: Eduem, 2007.

VIEIRA, J. M. Entrevista concedida à equipe do Serviço de Recursos Audiovisuais da Secretaria de Educação e Cultura de Maringá. Acervo Divisão de Patrimônio Histórico e Cultural. Maringá-PR: PMM, 1992.

VILLALOBOS, J. U. G. Maringá: Fundos de vale, política, legislação e situação ambiental. In: MORO, Dalton Áureo. Maringá espaço e tempo. Ensaio de Geografia Urbana. Programa de Pós-Graduação em Geografia. Maringá-PR: UEM, 2003. 